\title{
Forums For Accounting Information Systems Scholars
}

Lloyd D. Doney, C.D.P., C.D.E., Marquette University

Tim V. Eaton, C.P.A., (E-mail: tim.eaton@marquette.edu), Marquette University

\begin{abstract}
Previous studies ranking the quality of journals as a measure of the research contributions of accounting faculty have not served accounting information systems faculty well due to one or more of four problems: (1) the ranking included several highly-ranked accounting journals that publish few, if any, articles in the systems area; (2) the results did not include a separate ranking for those who teach in the systems area; (3) the survey did not include a sufficient number of journals from the information systems area that afford quality publishing opportunities for accounting faculty; and (4) the survey was completed by many accounting faculty who have little knowledge of or interest in the accounting systems area.
\end{abstract}

This study was undertaken to produce a ranking of journal quality specifically suited to judging the research contributions of accounting systems faculty. The survey methodology addresses each of the four problem areas cited above, resulting in rankings that are substantially different from other studies. Rather than the Accounting Review and Journal of Accounting Research leading the list of ranked journals, this study reveals that, for accounting information systems faculty, a top-ranked publication would appear either in MIS Quarterly or Management Science, both nonaccounting journals, as well as Journal of Information Systems (Accounting) or International Journal of Accounting Information Systems (formerly, Advances in Accounting Information Systems).

\subsection{Introduction and Motivation}

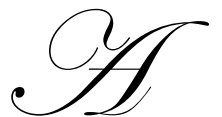

ssessing the quality of an accounting professor's publications is an important aspect of both the promotion and tenure and the annual performance evaluation process. While a number of factors may be considered in each case, one input that is often used is a peer ranking of journal quality. In recent years several studies have been published that render such a ranking for particular disciplines.

While these studies have provided a useful tool for those who must judge the quality of a faculty member's research performance, from the perspective of those who teach in the area of accounting information systems, previous studies in the accounting area have suffered one or more of four limitations:

- $\quad$ The ranking included several highly-ranked accounting journals that publish few, if any, articles in the accounting systems area.

- $\quad$ The results did not include a separate ranking for those who teach primarily in the accounting systems area.

- $\quad$ The survey did not include a sufficient number of journals from the information systems area that afford publishing opportunities for accounting faculty in view of the intersection of the two disciplines.

- $\quad$ The survey was completed by many accounting professors who have little knowledge of or interest in the accounting information systems area.

Readers with comments or questions are encouraged to contact the authors via email. 
Brown and Huefner (1994) found that the top five ranked journals were The Accounting Review, Journal of Accounting Research, Journal of Accounting and Economics, Contemporary Accounting Research and Accounting, Organizations and Society. While this ranking may be useful in evaluating the research of accounting faculty, generally, a study by Doney (1998) suggests that it may be unrealistic to expect that many AIS professors would publish in these highly-ranked journals. In reviewing the articles published in each of these journals for the years 1993 1997, he found only seven of 622 articles with AIS content. The Accounting Review had two of the articles, and Journal of Accounting Research, one. Three articles appeared in Accounting, Organizations \& Society; one in Contemporary Accounting Research; and none in Journal of Accounting and Economics.

Earlier studies by Arnold (1993) and Hull and Wright (1990) also placed these journals high in the rankings. Both ranked Journal of Accounting Research as number one and The Accounting Review as number two. Neither the Arnold nor the Hull and Wright study included Contemporary Accounting Research, and ranked Accounting, Organizations and Society as either number six or seven.

In addition to reporting the ranking for all respondents, Hull and Wright also reported separate rankings for respondents whose area of specialization was either financial, managerial, auditing or tax. In each instance The Accounting Review and Journal of Accounting Research were ranked either number one or two. There was some difference among the specializations in the inclusion of the three other journals making up the top five. There was no separate tabulation for those specializing in AIS, though by 1990 AIS courses were commonly included in the accounting curriculum. Brown and Huefner also included separate rankings for financial, managerial, auditing and tax with no separate ranking for AIS.

Arnold included several rankings in view of respondent characteristics, including rank, doctoral versus master/bachelors degree granting, and accredited versus overall. Most importantly, Arnold provided a comparison of the overall ranking verses the ranking of those respondents who indicated that their primary research area was information systems. This is a notable contribution of the Arnold study from an AIS perspective.

The Hull and Wright study included 79 journals. Of this total, four could be regarded as information systems journals. Similarly, the Brown and Huefner study, which included 44 journals, included a single journal that could be characterized as a systems journal. On the other hand, the Arnold study included at least a dozen information systems journals among the 80 included in the study. Nevertheless, most of the journals were in the areas of accounting and finance, including several that were specifically in the area of taxation.

The Hull and Wright rankings were based upon 278 responses. The respondents came from a list of participants selected from Hasselback's Accounting Faculty Directory. Included were all faculty with an earned doctorate or LLM and teaching at a U.S. institution. Brown and Huefner based their rankings on 181 responses. The respondents came from a sample of senior faculty at institutions named by the 1991 edition of Business Week as the best 40 MBA programs. Only full and associate professors were surveyed to ensure that all respondents were experienced academics.

Arnold's study was based upon a total of 138 responses. The respondents were drawn from the Information Systems/Management Advisory Services section of the American Accounting association. The Accounting Faculty Directory (Hasselback, 1992) was used to eliminate section members who were graduate students, publishing company representatives or accounting practitioners. Presumably, the faculty members included were of all ranks and included some masters as well as doctorally qualified individuals.

Each of these earlier studies made a valuable contribution to the task of evaluating the research productivity of accounting faculty. But from an AIS faculty member's perspective each suffered from one or more of the limitations initially enumerated. All three studies included The Accounting Review and Journal of Accounting Research, which earned a rank of one and two, respectively, in all three studies. The Journal of Accounting and Economics and Accounting, Organizations and Society were also ranked highly in all three of the studies. Contemporary Accounting Research was included in one study and also gained a high ranking. Since Doney found at least some evidence that these journals do not appear to be inclined to publish items in the AIS area, it benefits AIS professors lit- 
tle to be judged on the basis of whether or not they have published in the "top five" journals in accounting as reported in these studies.

Two of the studies, while providing a separate ranking for financial, managerial, auditing and tax, did not provide a separate ranking for AIS faculty. Given the substantial differences between the traditional accounting areas and systems, these separate rankings provide little benefit to the AIS educator. One study, the Arnold piece, addressed AIS faculty exclusively, and is notable in that respect.

The study by Arnold included a limited number of systems-oriented journals in the list of journals to be ranked, but several others could have been included. With a couple of exceptions the other two studies limited the list of journals to accounting journals.

Finally, two of the studies included respondents from all of the accounting specialty areas. Again in view of the substantial differences between the traditional accounting areas and systems, there may be some risk that the survey was completed by many who had little knowledge of or interest in the accounting information systems area, limiting the usefulness of the ranking for AIS faculty.

\subsection{Research Methodology}

In view of the above limitations of the prior studies, this study was structured to:

1. Omit certain highly ranked accounting journals that have published very few systems articles in recent years;

2. $\quad$ Limit the study so that the results are relevant to AIS faculty;

3. Include a sufficient number of journals from the information systems area which afford publishing opportunities for AIS faculty;

4. Survey only AIS faculty.

\subsection{Journal Selection}

An initial list of accounting journals to be used in this study was compiled from the three articles previously discussed. An initial list of MIS journals was obtained from a study of journal rankings for MIS researchers compiled by Hardgrave and Walstrom (1997). The total journal listing that resulted was pared by eliminating duplicates, removing the previously cited A "top five" accounting journals, and eliminating specialty journals in the areas of tax, finance and economics, which are not likely outlets for AIS items.

Using information available in the current issues of Accounting and Tax Index, Cabell's Directory of Publishing Opportunities in Accounting, and Cabell's Directory of Publishing Opportunities in Management, many but not all journals which were not blind refereed were stricken from the list. These sources also supplied information with respect to both newer and other appropriate journals that were added to the list from both the accounting and IT areas. The resulting tabulation of journals resulted in a collection of over eighty items.

At this point, the authors decided that the list of journals to be ranked should be limited to fifty items to facilitate the responses of those queried. To delete more items from the list, the above sources were again used, examining the stated publishing interest of the journals. On this basis additional journals were removed resulting in the desired tabulation of fifty items.

Twenty of the journals included in the final list of journals to be ranked can be classified as accounting journals. Another twenty-four can be typed as information technology journals. The remaining six journals can be appropriately described as dual-purpose journals, falling in the intersection of AIS and IT. Using this classification, the final list of journals was compiled and is included in Table 1. 
Table 1- Journals Included in Survey

\author{
Accounting Journals \\ Accounting Educator's Journal \\ Accounting Horizons \\ Accounting Systems Journal \\ Advances in Accounting Information Systems \\ Advances in Accounting \\ Auditing: A Journal of Practice and Theory \\ Behavioral Research in Accounting \\ CPA Journal \\ Internal Auditing \\ Internal Auditor \\ Issues in Accounting Education \\ Journal of Accountancy \\ Journal of Accounting and Computers \\ Journal of Accounting Education \\ Journal of Accounting, Auditing and Finance \\ Journal of Information Systems (Accounting) \\ Journal of Management Accounting Research \\ Management Accounting/Strategic Finance \\ New Accountant \\ Review of Accounting Information Systems
}

\section{IT Journals}

Academy of Management Journal

Academy of Management Review

Behavior and Information Technology

Communications of the ACM

Computers in Human Behavior

Expert Systems with Applications

Information and Management

Information Resources Management Journal

Information Systems Journal

Information Systems Management

Information Systems Research

Interfaces

Journal of Computer Information Systems

Journal of Data Base Management

Journal of End User Computing

Journal of Information Systems (Education)

Journal of Information Technology

Journal of Information Technology Management

Journal of Intelligent Information Systems

Journal of Management Information Systems

Journal of Strategic Information Systems

Journal of Systems and Software

Management Science

MIS Quarterly

\section{Cross Disciplinary Journals}

Academy for Information and Management Sciences Journal

Accounting, Management and Information Technologies

Decision Sciences

Harvard Business Review

International Journal of Intelligent Systems in Accounting, Finance and Management

Journal of Applied Business Research
The fifty journals were presented on the survey instrument in alphabetical order, without regard to category, to preclude any response bias related to either discipline or listing order. In addition to rating each of the journals on a scale of 1 (lowest) - 5 (highest), each respondent was asked to supply and rate up to three journals that should have been included. Respondents were also asked to name their top three journals for AIS articles.

\subsection{Results}

\subsection{Demographics}

The population of respondents included senior accounting faculty who teach and research in the systems area, as identified in the current electronic version of Hasselback (2001/2002). In addition to associate and full professors, those who identified themselves as deans, directors or chairs were also included as were those who identified their area specialty as computer. The respondent group was limited to senior faculty on grounds that they were more likely to have compiled a list of journal publications in the systems area as well as more likely to be involved in rank and tenure and periodic performance evaluations.

In what proved to be a case of bad timing the initial mailing to 470 was mailed in early September, 2001. Only 63 useable surveys were returned over the next eight weeks. The returns reflected a shortfall of responses from the East Coast, probably reflecting the frightening anthrax problems in post offices in that area. Accordingly, a follow-up mailing was made in January of 2002. This mailing rendered an additional 38 responses, for a total of 101 responses. The resulting total number of respondents was judged adequate to provide useful information to the probable users of the journal rankings that the responses would yield.

In addition to rating each of the fifty journals, respondents were asked to supply additional information, including: rank, AACBS accreditation, highest degree offered, years teaching AIS course, chair re- 
sponsibilities, and number of refereed publications. Table 2 provides a summary of the demographics of the respondents. A little over 60 percent were associate professors. Almost 12 percent had administrative responsibilities. The vast majority (88\%) were from AACSB accredited schools. The authors were pleased to note that the mean years teaching AIS was 11.2 years, and that the mean number of blind-refereed publications was 17.9.

Table 2- Respondent Demographics

\begin{tabular}{|c|c|}
\hline Rank & $61.4 \%$ Associate \\
& $38.6 \%$ Full \\
\hline Accreditation (AACSB) & $88.3 \%$ Yes \\
& $11.7 \%$ No \\
\hline Highest Degree Offered & $3.2 \%$ PHD \\
& $55.9 \%$ Masters \\
\hline Percentage Chairman, & $40.9 \%$ Bachelors \\
Dean, or Director & \\
\hline Years Teaching & Yhairman, Dean, Director 11.8\% Teaching AIS \\
& Range (0-35) Mean 11.2 \\
\hline Number of Blind & Publications (blind review) \\
Refereed Publications & Mean 17.9 \\
& \\
\hline
\end{tabular}

\subsection{Journal Familiarity}

Table 3 provides information on the survey respondents familiarity with the journals listed in the survey. As discussed in the section on research methodology much care was taken in determining the list of journals to include. The most familiar journals were generally those with an accounting perspective including Accounting Horizons and Journal of Accountancy tied for the top at $89 \%$. Also, the AAA published journal Issues in Accounting Education was familiar to $84 \%$ of respondents. Beyond accounting, however, several other journals were familiar to over two-thirds of respondents including Harvard Business Review (80\%), Decision Sciences (77\%), Management Science (70\%), and MIS Quarterly

(68\%). Among the least familiar were Journal of Intelligent Information Systems (19\%), Journal of Systems and Software and Journal of Information Technology Management, both at $21 \%$.

\subsection{Journal Ratings}

The ranked listing of overall journal ratings is provided in Table 4. Interestingly, there is not a direct correspondence between familiarity and ratings. On a scale of 1 (lowest) to 5 (highest), the highest ranked journals were not accounting journals. MIS quarterly was ranked first, followed by Management Science and Decision Sciences. The two most familiar journals, Accounting Horizons and Journal of Accountancy, were rated relevatively lower in the overall journal ratings. The highest rated accounting journal was Journal of Information Systems (Accounting).

Most of the journals were perceived to be of at least moderate quality with one exception. The New Accountant was clearly the lowest rated journal (1.82 on a 5 point scale) having a fair degree of separation from the next lowest journal the Journal of End User Computing (2.71).

Respondents also were given an opportunity to list any journals they felt should have been included in the survey but were not. For the most part it appears as if our selection process described in the research methodology section was successful. A total of thirteen additional journals were listed as provided in Table 5. However, eight of the thirteen journals were listed by only one individual. Of the five journals listed by multiple respondents, three are the traditionally top ranked journals (Journal of Accounting Research, Contemporary Accounting Research, and Accounting Review), which were intentionally omitted from this survey since they do not tend to publish systems articles. The remaining two should have been included. Advances in Accounting Behavioral Research, a relatively new journal, was mentioned by three individuals. The most frequently listed journal was International Journal of Accounting Information Systems, cited by approximately 5 percent of respondents. This journal is the successor journal to Advances in Accounting Information Systems. In hindsight, the authors should have dual listed this journal under both names. 
Table 3-Journal Familiarity

\begin{tabular}{|c|c|c|}
\hline Rank & Journal & Percentage Familiar \\
\hline 1 & Accounting Horizons & $89 \%$ \\
\hline 1 & Journal of Accountancy & $89 \%$ \\
\hline 3 & Issues in Accounting Education & $84 \%$ \\
\hline 4 & Harvard Business Review & $80 \%$ \\
\hline 5 & Auditing: A Journal of Practice and Theory & $79 \%$ \\
\hline 6 & Decision Sciences & $77 \%$ \\
\hline 7 & CPA Journal & $74 \%$ \\
\hline 7 & Journal of Information Systems (Accounting) & $74 \%$ \\
\hline 9 & Journal of Accounting Education & $71 \%$ \\
\hline 10 & Management Science & $70 \%$ \\
\hline 11 & Accounting Educator's Journal & $69 \%$ \\
\hline 12 & Journal of Accounting, Auditing, and Finance & $68 \%$ \\
\hline 12 & MIS Quarterly & $68 \%$ \\
\hline 14 & Advances in Accounting Information Systems & $64 \%$ \\
\hline 14 & Behavioral Research in Accounting & $64 \%$ \\
\hline 16 & New Accountant & $60 \%$ \\
\hline 16 & Advances in Accounting & $60 \%$ \\
\hline 18 & Communications of the ACM & $58 \%$ \\
\hline 18 & Journal of Management Accounting Research & $58 \%$ \\
\hline 20 & Internal Auditing & $56 \%$ \\
\hline 20 & Internal Auditor & $56 \%$ \\
\hline 22 & Review of Accounting Information Systems & $52 \%$ \\
\hline 23 & Journal of Applied Business Research & $51 \%$ \\
\hline 24 & Academy of Management Journal & $50 \%$ \\
\hline 25 & Academy of Management Review & $46 \%$ \\
\hline 25 & Information Systems Research & $46 \%$ \\
\hline 25 & Journal of Management Information Systems & $46 \%$ \\
\hline 28 & International Journal of Intelligent Systems in Accounting, Finance, and Management & $44 \%$ \\
\hline 28 & Management Accounting/Strategic Finance & $44 \%$ \\
\hline 30 & Interfaces & $42 \%$ \\
\hline 31 & Journal of Accounting and Computers & $41 \%$ \\
\hline 32 & Information Systems Journal & $40 \%$ \\
\hline 33 & Accounting, Management and Information Technologies & $37 \%$ \\
\hline 33 & Accounting Systems Journal & $37 \%$ \\
\hline 35 & Journal of Computer Information Systems & $36 \%$ \\
\hline 35 & Journal of Data Base Management & $36 \%$ \\
\hline 37 & Information and Management & $35 \%$ \\
\hline 38 & Expert Systems with Application & $34 \%$ \\
\hline 39 & Journal of Information Systems (Education) & $32 \%$ \\
\hline 40 & Journal of End User Computing & $28 \%$ \\
\hline 41 & Journal of Strategic Information Systems & $26 \%$ \\
\hline 41 & Information Resources Management Journal & $26 \%$ \\
\hline 43 & Information Systems Management & $24 \%$ \\
\hline 44 & Academy of Information and Management Sciences Journal & $23 \%$ \\
\hline 44 & Computers in Human Behavior & $23 \%$ \\
\hline 46 & Behavior and Information Technology & $22 \%$ \\
\hline 46 & Journal of Information Technology & $22 \%$ \\
\hline 48 & Journal of Systems and Software & $21 \%$ \\
\hline 48 & Journal of Information Technology Management & $21 \%$ \\
\hline 50 & Journal of Intelligent Information Systems & $19 \%$ \\
\hline
\end{tabular}


Table 4-Journal Ratings [1(lowest)-5(highest)]

\begin{tabular}{|c|c|c|}
\hline Rank & Journal & Mean Ratings \\
\hline 1 & MIS Quarterly & 4.43 \\
\hline 2 & Management Science & 4.31 \\
\hline 3 & Decision Sciences & 4.25 \\
\hline 4 & Information Systems Research & 4.24 \\
\hline 4 & Journal of Information Systems (Accounting) & 4.24 \\
\hline 6 & Communications of the ACM & 4.23 \\
\hline 7 & Auditing: A Journal of Practice and Theory & 4.20 \\
\hline 8 & Journal of Management Information Systems & 4.13 \\
\hline 9 & Harvard Business Review & 3.94 \\
\hline 10 & Journal of Accounting, Auditing, and Finance & 3.90 \\
\hline 10 & Journal of Management Accounting Research & 3.90 \\
\hline 12 & Issues in Accounting Education & 3.87 \\
\hline 13 & Academy of Management Journal & 3.86 \\
\hline 14 & Behavioral Research in Accounting & 3.81 \\
\hline 15 & Advances in Accounting Information Systems & 3.80 \\
\hline 15 & Information Systems Journal & 3.80 \\
\hline 17 & Accounting Horizons & 3.79 \\
\hline 18 & Academy of Management Review & 3.78 \\
\hline 19 & International Journal of Intelligent Systems in Accounting, Finance, and Management & 3.61 \\
\hline 20 & Advances in Accounting & 3.55 \\
\hline 21 & Accounting, Management and Information Technologies & 3.47 \\
\hline 22 & Expert Systems with Application & 3.47 \\
\hline 23 & Information and Management & 3.46 \\
\hline 24 & Journal of Accounting Education & 3.44 \\
\hline 25 & Journal of Computer Information Systems & 3.42 \\
\hline 25 & Journal of Strategic Information Systems & 3.42 \\
\hline 27 & Interfaces & 3.40 \\
\hline 28 & Journal of Applied Business Research & 3.39 \\
\hline 29 & Journal of Intelligent Information Systems & 3.37 \\
\hline 29 & Behavior and Information Technology & 3.27 \\
\hline 29 & Journal of Accountancy & 3.27 \\
\hline 32 & Information Systems Management & 3.25 \\
\hline 32 & Journal of Information Systems (Education) & 3.25 \\
\hline 33 & Journal of Data Base Management & 3.22 \\
\hline 35 & Review of Accounting Information Systems & 3.21 \\
\hline 36 & Academy of Information and Management Sciences Journal & 3.17 \\
\hline 37 & Accounting Systems Journal & 3.14 \\
\hline 38 & Journal of Information Technology Management & 3.10 \\
\hline 39 & Journal of Information Technology & 3.09 \\
\hline 40 & Internal Auditor & 3.07 \\
\hline 40 & Journal of Accounting and Computers & 3.07 \\
\hline 40 & Management Accounting/Strategic Finance & 3.07 \\
\hline 43 & Accounting Educator's Journal & 3.06 \\
\hline 44 & Journal of Systems and Software & 3.00 \\
\hline 45 & Computers in Human Behavior & 2.96 \\
\hline 45 & Information Resources Management Journal & 2.96 \\
\hline 47 & Internal Auditing & 2.93 \\
\hline 48 & CPA Journal & 2.88 \\
\hline 49 & Journal of End User Computing & 2.71 \\
\hline 50 & New Accountant & 1.82 \\
\hline
\end{tabular}


Table 5-Journals Added by Survey Respondents

\begin{tabular}{|l|c|}
\hline \multicolumn{1}{|c|}{ Journal } & Number Mentioned \\
\hline International Journal of Accounting Information Systems & $(5)$ \\
\hline Accounting Review & $(3)$ \\
\hline Advances in Accounting Behavioral Research & $(3)$ \\
\hline Contemporary Accounting Research & $(2)$ \\
\hline Journal of Accounting Research & $(1)$ \\
\hline Journal of Research on Computing Education & $(1)$ \\
\hline Accounting Organization and Society & $(1)$ \\
\hline Communications of the Association of Information Systems & $(1)$ \\
\hline Journal of Accounting and Finance Research & $(1)$ \\
\hline Journal of the Association of Information Systems & \\
\hline Journal of Managerial Issues & \\
\hline
\end{tabular}

\subsection{Journal Rankings}

Finally, respondents were given an opportunity to provide their rankings of the top three journals. These results are provided in Table 6. Overwhelmingly, Journal of Information Systems (Accounting) was perceived to be the top ranked. Over a third of respondents listed it first and a total of over $60 \%$ placed it in the top three ranked journals. A non-accounting journal, MIS Quarterly, was a somewhat distant second with over $38 \%$ ranking it in the top three journals. Almost one-third (29\%) of respondents listed Advances in Accounting Information Systems/International Journal of Accounting Information Systems as a top journal. The next highest ranked journal, Decision Sciences, was perceived to be a top journal by about $20 \%$ of respondents. Comparing these results to familiarity in Table 2 and the ratings listed in Table 3 yields some interesting results. Journal of Information Systems (Accounting) was only familiar to $74 \%$ of respondents, somewhat lower than other journals. It was tied for fourth in overall ratings, but in the respondent listing of the top three ranked journals, it is clearly the perceived top journal. MIS Quarterly was only familiar to about two-thirds of respondents yet in overall ratings it was the top journal. However, in the respondent listing of the top three ranked journals, it fell below Journal of Information Systems (Accounting). The top two most familiar journals, Accounting Horizons and Journal of Accountancy, were listed by only $7.1 \%$ and $5 \%$ of survey respondents, respectively. Finally, the other significant accounting systems journal is the International Journal of Accounting Information Systems (formerly Advances in Accounting Information Systems), only $64 \%$ were familiar with the journal. In the mean ratings, it was perceived well (in the top third of journals in our survey). However, in the final rankings of top journals, it was ranked quite high. Overall, it was in the top three journals and second only to Journal of Information Systems in accounting journals. 
Table 6-Top-Three Ranked Journals

\begin{tabular}{|c|c|c|c|c|}
\hline 1avic ot & Ranked $1^{\text {st }}$ & Ranked $2^{\text {nd }}$ & Ranked $3^{\text {rd }}$ & Total \\
\hline Journal of Information Systems (Accounting) & $37.5 \%$ & $10.9 \%$ & $12.5 \%$ & $60.9 \%$ \\
\hline MIS Quarterly & $14.1 \%$ & $18.8 \%$ & $5.4 \%$ & $38.3 \%$ \\
\hline $\begin{array}{l}\text { Advances in Accounting Information Systems/International } \\
\text { Journal of Accounting Information Systems }\end{array}$ & $7.9 \%$ & $14.0 \%$ & $7.1 \%$ & $29.0 \%$ \\
\hline Decision Sciences & $3.1 \%$ & $6.3 \%$ & $12.5 \%$ & $21.9 \%$ \\
\hline Information Systems Research & $6.3 \%$ & $7.8 \%$ & $1.8 \%$ & $15.9 \%$ \\
\hline Review of Accounting Information Systems & $3.1 \%$ & $7.8 \%$ & $3.6 \%$ & $14.5 \%$ \\
\hline Issues in Accounting Education & $0 \%$ & $3.1 \%$ & $7.1 \%$ & $10.2 \%$ \\
\hline Journal of Management Information Systems & $6.3 \%$ & $0 \%$ & $3.6 \%$ & $9.9 \%$ \\
\hline Management Science & $4.7 \%$ & $3.1 \%$ & $1.8 \%$ & $9.6 \%$ \\
\hline Journal of Information Systems & $4.7 \%$ & $3.1 \%$ & $0 \%$ & $7.8 \%$ \\
\hline Accounting Horizons & $0 \%$ & $0 \%$ & $7.1 \%$ & $7.1 \%$ \\
\hline $\begin{array}{l}\text { International Journal of Intelligent Systems in Accounting, } \\
\text { Finance, and Management }\end{array}$ & $0 \%$ & $1.6 \%$ & $5.4 \%$ & $7.0 \%$ \\
\hline Journal of Accountancy & $1.6 \%$ & $1.6 \%$ & $1.8 \%$ & $5.0 \%$ \\
\hline Accounting, Management and Information Technologies & $0 \%$ & $3.1 \%$ & $1.8 \%$ & $4.9 \%$ \\
\hline Auditing: A Journal of Practice and Theory & $0 \%$ & $3.1 \%$ & $1.8 \%$ & $4.9 \%$ \\
\hline Communications of the ACM & $3.1 \%$ & $0 \%$ & $3.6 \%$ & $3.7 \%$ \\
\hline Accounting Educator's Journal & $0 \%$ & $0 \%$ & $3.6 \%$ & $3.6 \%$ \\
\hline Behavioral Research in Accounting & $0 \%$ & $0 \%$ & $3.6 \%$ & $3.6 \%$ \\
\hline CPA Journal & $0 \%$ & $0 \%$ & $3.6 \%$ & $3.6 \%$ \\
\hline Harvard Business Review & $0 \%$ & $1.6 \%$ & $1.8 \%$ & $3.4 \%$ \\
\hline
\end{tabular}

\subsection{Conclusions}

Accounting information systems as a specialty area in accounting education is in its third decade and the most recent issue of the Accounting Faculty Directory identifies 844 faculty who identify themselves as systems faculty in the U. S. Nevertheless, in many institutions systems faculty struggle to be recognized as a specialty having research characteristics and publishing opportunities that are quite different than those who specialize in auditing, tax, financial or managerial accounting. One of the difficulties in gaining this recognition has been a suitable ranking of journals that could be used to evaluate the quality of their research.

This study provides a ranking of journals suitable to evaluating the published research of AIS faculty. As anticipated by the authors, the rankings produced by this survey are strikingly different from the previously published rankings of accounting journals that are suitable for evaluating the research of faculty in auditing, tax, financial and managerial accounting, but not for those in the systems area.

It is the hope of the authors, that the results of this study will provide those who must evaluate the research of AIS faculty with a tool that is not only more suitable, but also more fair in making such judgments.

The authors believe that the results of this study will give those charged with the responsibility of evaluating the research of accounting information systems faculty a more suitable vehicle for making those judgments.

\section{References}

1. Accounting and Tax Index. 1999. Ann Arbor: University of Michigan.

2. Arnold, Vicky. 1993. Accounting Information Systems Research: Attitudes and Perceptions of Publication Outlets. Advances in Accounting Information Systems 2: 133-160.

3. Brown, Lawrence D. and Ronald J. Huefner. 1994. The Familiarity with and Perceived Quality of Accounting Journals: Views of Senior Accounting Faculty in Leading U.S. MBA Programs. Contemporary Accounting Research 11: 223-249. 
4. Cabell's Directory of Publishing Opportunities in Accounting, $8^{\text {th }}$ edition. 2001/02. Beaumont, Texas: Cabell Publishing Company.

5. Cabell's Directory of Publishing Opportunities in Management, $8^{\text {th }}$ edition. 2001/02. Beaumont, Texas: Cabell Publishing Company.

6. Doney, Lloyd D. 1998. AIS Articles in Top-Ranked Accounting Journals, 1993-1997. The Review of Accounting Information Systems 2: 17-23.

7. Hardgrave, Bill C. and Kent A, Walstrom. 1997. Forums For MIS Scholars. Communications of the ACM 40: 119-124.

8. Hull, Rita P. and Gail B. Wright. 1990. Faculty Perceptions of Journal Quality: An Update. Accounting Horizons 16: 77-98.

Notes 